\title{
Unravelling the neurophysiological basis of aggression in a fish model
}

\author{
Amy L Filby ${ }^{*}$, Gregory C Paull, Tamsin FA Hickmore, Charles R Tyler
}

\begin{abstract}
Background: Aggression is a near-universal behaviour with substantial influence on and implications for human and animal social systems. The neurophysiological basis of aggression is, however, poorly understood in all species and approaches adopted to study this complex behaviour have often been oversimplified. We applied targeted expression profiling on 40 genes, spanning eight neurological pathways and in four distinct regions of the brain, in combination with behavioural observations and pharmacological manipulations, to screen for regulatory pathways of aggression in the zebrafish (Danio rerio), an animal model in which social rank and aggressiveness tightly correlate.

Results: Substantial differences occurred in gene expression profiles between dominant and subordinate males associated with phenotypic differences in aggressiveness and, for the chosen gene set, they occurred mainly in the hypothalamus and telencephalon. The patterns of differentially-expressed genes implied multifactorial control of aggression in zebrafish, including the hypothalamo-neurohypophysial-system, serotonin, somatostatin, dopamine, hypothalamo-pituitary-interrenal, hypothalamo-pituitary-gonadal and histamine pathways, and the latter is a novel finding outside mammals. Pharmacological manipulations of various nodes within the hypothalamoneurohypophysial-system and serotonin pathways supported their functional involvement. We also observed differences in expression profiles in the brains of dominant versus subordinate females that suggested sexconserved control of aggression. For example, in the HNS pathway, the gene encoding arginine vasotocin (AVT), previously believed specific to male behaviours, was amongst those genes most associated with aggression, and AVT inhibited dominant female aggression, as in males. However, sex-specific differences in the expression profiles also occurred, including differences in aggression-associated tryptophan hydroxylases and estrogen receptors.

Conclusions: Thus, through an integrated approach, combining gene expression profiling, behavioural analyses, and pharmacological manipulations, we identified candidate genes and pathways that appear to play significant roles in regulating aggression in fish. Many of these are novel for non-mammalian systems. We further present a validated system for advancing our understanding of the mechanistic underpinnings of complex behaviours using a fish model.
\end{abstract}

\section{Background}

The display of aggression is a near-universal trait in the animal kingdom, of which several forms have been distinguished [1]. In non-human animals, aggression typically occurs in the context of competition for limited resources, including food, mates and nesting sites, where it is important in the establishment of territories and dominance hierarchies. In this respect, aggression is viewed as an adaptation that can have key effects on the

\footnotetext{
* Correspondence: a.lfilby@exeter.ac.uk
School of Biosciences, University of Exeter, Hatherly Laboratories, Prince of

* Correspondence: a.lfillby@exeter.ac.uk
School of Biosciences, University of Exeter, Hatherly Laboratories, Prince of Wales Road, Exeter, Devon EX4 4PS, UK
}

lifelong success of individuals and that conveys evolutionary fitness [2]. In humans, expression of aggression out of the appropriate context is, in contrast, currently recognised as one of the greatest and most challenging problems in society and has been identified as a key area for research and pharmacological intervention $[3,4]$. Despite the impacts of aggression in social systems and the plethora of studies in this area, its neurophysiological basis is not well understood in any species.

One factor likely contributing to the limited knowledge on the control of aggression is that studies in this area have generally focused on linking specific 
neurotransmitters/neuroendocrine factors from individual pathways with the expression of aggressive behaviours. This approach does not build an understanding of the combination of factors and their interactions that form the biological determinants of this behaviour. Given that aggression is a complex behavioural display, multifactorial control is expected [5]. Gene expression profiling, therefore, offers considerable potential for unravelling the complexities of its control. This is because the expression of many genes representing different pathways can be assessed simultaneously in the same individual [6,7]. Expression profiling approaches to studying the brain have already enhanced knowledge in other areas of behavioural science, including learning and memory, courtship behaviour and mate choice, reward behaviour, and disorders such as depression, schizophrenia and Parkinson's disease [8-12]. Only recently, however, has this approach begun to be applied in the study of aggression. Moreover, this work has largely focused on a few select laboratory models (Drosophila and mouse [13-18]), although has also included the chicken [19] and honey bee [7].

The zebrafish (Danio rerio) is used extensively for research on development and medicine [20], and is now also emerging as a model for studying animal behaviour [21]. The zebrafish is a group-living species in which dominance hierarchies form in both sexes (at least in captivity). Aggression is used commonly by dominant individuals to enable them to occupy territories over spawning sites and protect their status from their subordinates [22-24]. This close association between aggression and social rank, together with the zebrafish's less complex behavioural patterns compared with mammals, make the zebrafish highly appropriate for mechanistic studies for understanding aggression. Surprisingly, despite the wealth of studies quantifying aggression in zebrafish and the potential for the application of genomic tools for understanding the mechanisms of this behaviour, only one study (and investigating only a single neuropeptide) has explored its neurophysiological underpinnings [22].

In this study, we set out to investigate the neurophysiological basis of aggression in zebrafish. To do so, we applied a targeted approach, profiling the expression of 40 genes to identify neurological signalling pathways associated with the production of agonistic behaviors. This was achieved by comparing the brains of zebrafish of different social ranks that differed in their level of aggressiveness. Within this experiment, we included comparisons of different regions of the brain, explored possible sex-related differences and quantified temporal changes in the patterns of gene expression associated with changes in behaviour. Our integrated approach enabled us to link differences in the expression of cascades of genes associated with a wide range of neurological signalling pathways with differences in the levels of aggression. We then performed specific pharmacological manipulations on some of the neurological pathways highlighted as potentially of importance in controlling aggression. These manipulations tested for the functional involvement, and possibly sex-specific roles, of these pathways in aggression in zebrafish.

\section{Results/Discussion}

In this study, we applied gene expression profiling combined with behavioural analysis on individuals in small social groups to initiate an understanding of the neurophysiological basis of aggression in the zebrafish, our experimental model. For this work, 40 genes were selected based on their reported roles in aggression in mammals. These genes spanned eight interrelated neurological pathways: the hypothalamo-neurohypophysialsystem (HNS), serotonin (5-HT), somatostatin, dopamine, histamine, nitric oxide, hypothalamo-pituitaryinterrenal (HPI) and hypothalamo-pituitary-gonadal (HPG) pathways (Fig. 1). The expression of these genes in the brains of males and females was then compared between dominant and subordinate fish since they displayed different levels of aggressive behaviour (high and low, respectively. We subsequently performed pharmacological manipulations on dominant males and/or females, administering specific agents (known to be effective in mammals) to agonise, antagonise, or inhibit particular receptors or transporters within the neurological pathways identified. We then quantified the outcomes on aggression compared with sham administrations to assess possible roles of those pathways in the regulation of the aggressive behaviours characterised.

\section{Differences in aggressiveness between social ranks and sexes}

As expected, dominant fish, as quantified by summed frequencies of the specific behaviours of chasing, sparring and repelling, were more aggressive than subordinate fish (Two-way ANOVA: $F_{1,58}=45.769 ; P<0.001$; Fig. 2), in accordance with that described previously for this species [22,24]. Males were more aggressive than females (Two-way ANOVA: $F_{1,58}=21.967 ; P<0.001$ ), although the effect of sex on aggression depended on social rank (Two-way ANOVA: $F_{1,58}=14.984 ; P<$ $0.001)$ : dominant males were more aggressive than dominant females but there was no difference in aggression between subordinate males and females (Fig. 2). These data are in keeping with previous findings for this strain of zebrafish [24]. In contrast, Moretz et al. [25] observed no sex differences in the aggression of zebrafish. However, their study used a different measure of 


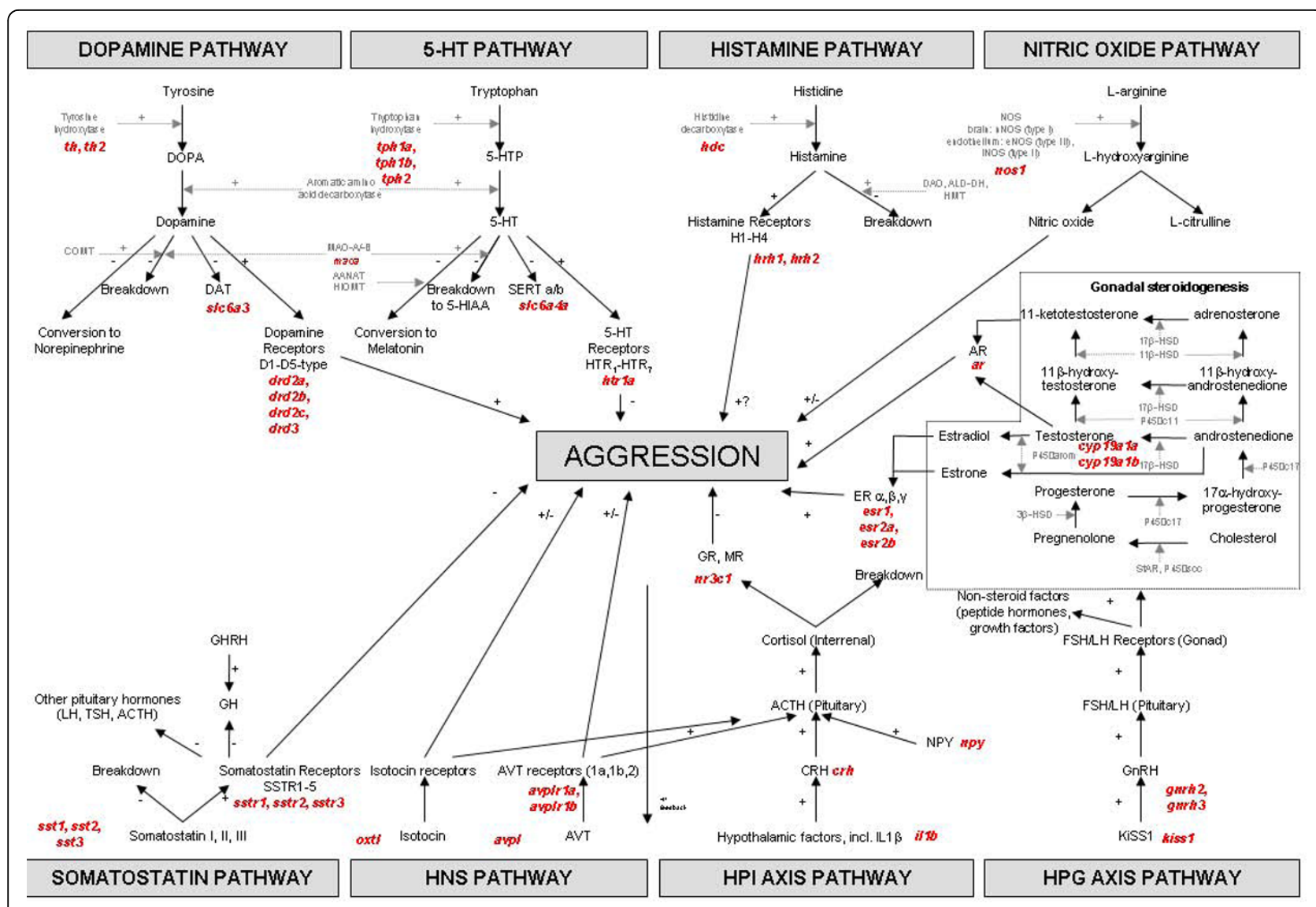

Figure 1 Simplified schematic of regulatory neurological pathways of aggression in mammals targeted for this study in fish. Study genes are highlighted in red. Abbreviations: 5-HIAA, 5-hydroindoleacetic acid; 5-HT, 5-hydroxytryptamine (serotonin); 5-HTP, 5-hydroxytryptophan; AANAT, arylalkylamine N-acetyltransferase; ACTH, adrenocorticotropic hormone; ALD-DH, acetaldehyde dehydrogenase; AR, androgen receptor; $\mathrm{AVT}$, arginine vasotocin; COMT, catechol-O-methyl transferase; $\mathrm{CRH}$, corticotrophin releasing hormone; DAO, diamine oxidase; DAT, dopamine transporter; DOPA, dihydroxyphenylalanine; ER, estrogen receptor; FSH, follicle-stimulating hormone; GH, growth hormone; GHRH, growth hormone releasing hormone; GnRH, gonadotropin releasing hormone; GR, glucocorticoid receptor; HIOMT, hydroxyindole-O-methyltransferase; HMT, histamine-N-methyltransferase; HNS, hypothalamo-neurohypophysial system; HPI, hypothalamo-pituitary-interrrenal; HPG, hypothalamopituitary-gonadal; IL1 $\beta$, interleukin $1 \beta$; LH, luteinizing hormone; MAO, monoamine oxidase; MR, mineralocorticoid receptor; NOS, nitric oxide synthase; NPY, neuropeptide Y; SERT, 5-HT transporter; TSH, thyrotropin-stimulating hormone. Plus (+) and negative (-) symbols indicate the proposed action of a gene/neurotransmitter/pathway on aggression (i.e. stimulatory or inhibitory, respectively).

aggression (biting to a mirror stimulus) and different strains of zebrafish; in their studies, the choice of zebrafish strain was shown to have a significant influence on their behaviour results [25].

The body sizes (wet weights and fork lengths) of the fish used in the study were: dominant males, $0.374 \pm$ $0.009 \mathrm{~g}$ vs. subordinate males $0.331 \pm 0.102 \mathrm{~g}$ and 31.84 $\pm 0.32 \mathrm{~mm}$ vs. $30.20 \pm 0.37 \mathrm{~mm}$; dominant females $0.444 \pm 0.015 \mathrm{~g}$ vs. subordinate females $0.361 \pm 0.047 \mathrm{~g}$ and $32.27 \pm 0.50$ vs. $30.2 \pm 0.37 \mathrm{~mm}$, and dominants were significantly larger than subordinates [see [26]]. In the zebrafish used in this study, dominant males also sired more offspring (quantified through parentage analyses using DNA microsatellites on the resulting embryos [24]). This finding was in accordance with that shown previously in competitive breeding scenarios [23].
Dominant females used in this study also had a higher breeding success with the dominant males compared with their subordinates [24]. In our previous work, we have further shown that a higher social rank is correlated with an enhanced general health (e.g. immune and stress status [26]).

\section{Mapping regions of the brain associated with aggression}

We first determined regions of the brain associated with aggressiveness in zebrafish. This was achieved using males, based on their greater aggression, and greater differential in aggression between social ranks, than observed in females. We determined gene expression profiles in four regions of the brain in dominant compared with subordinate males, identified as such based on behavioural observations of aggression on day 1 of 


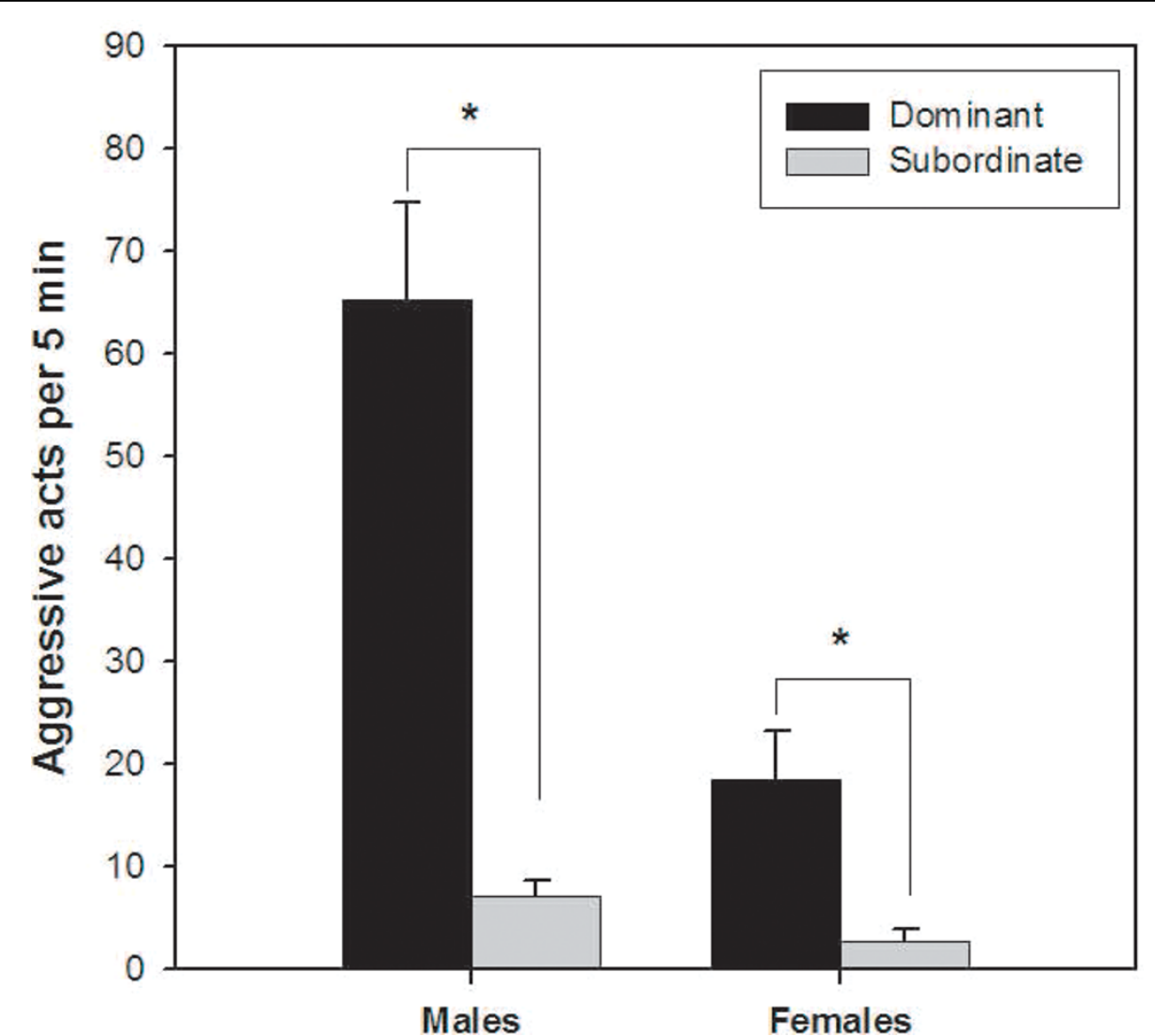

Figure 2 Correlation between social rank and aggressiveness in male and female zebrafish. The number of aggressive acts performed by each fish towards the other fish of the same sex in colonies with 2 males and 2 females ( $n=16$ fish per group) was quantified during a 5 min observation on the day of the sampling. Statistically significant differences in aggression were observed between social ranks for both sexes and between sexes $(P<0.001$; Two way ANOVA followed by Holm-Sidak post hoc test).

the social interaction experiment. In doing so, we observed marked differences with a total of 34 differentially expressed genes across the different brain regions (Fig. 3; for fold-differences and $P$ values see Additional File 1). While this number of differentially-expressed genes was relatively large, for the majority of the genes the significance values were between 0.05-0.01. These high values may reflect variability in gene expression between fish, which may have resulted from slight differences in the macroscopic brain dissection process between fish, and/or the modest sample size we used for our analyses ( $\mathrm{n}=8$ fish per group). Furthermore, had we established the relative aggression levels of all the fish used in the study and accounted for these in the statistical analyses of the gene expression data (rather than those between the four fish within each colony only), we may have been able to control for some of the variation observed in gene expression levels.

We observed considerable differences in the specific genes associated with social rank for the different regions of the brain. The greatest differences between social ranks, based on counts of differentially-expressed genes for the chosen set of 40 genes, occurred in the hypothalamus and telencephalon. Here, 17 genes and 8 genes, respectively, were differentially-expressed (Fig. 3). In these regions, the mean fold changes in expression for all genes in dominants compared to subordinates were also the highest (1.71- and 1.26-fold changes, compared to 1.14 and 0.98 -fold changes in the hindbrain and optic tectum). This finding in zebrafish is consistent with that occurring in mammals. In mammals, various forebrain structures play key roles in aggression, including the amygdala and hippocampus within the neocortex $[6,27]$, structures that are believed to be homologous to the medial and lateral telencephalon, respectively, in fish [28]. The hypothalamus is also an area associated with the control of aggression in mammals. In its intermediate regions it contains the 'attack area,' which mediates aggressive attacks partially via forebrain stimulation [29], and various neuroendocrine nuclei that regulate pituitary hormone release, for example the preoptic area (POA) located at its border with the ventral telencephalon [6]. 


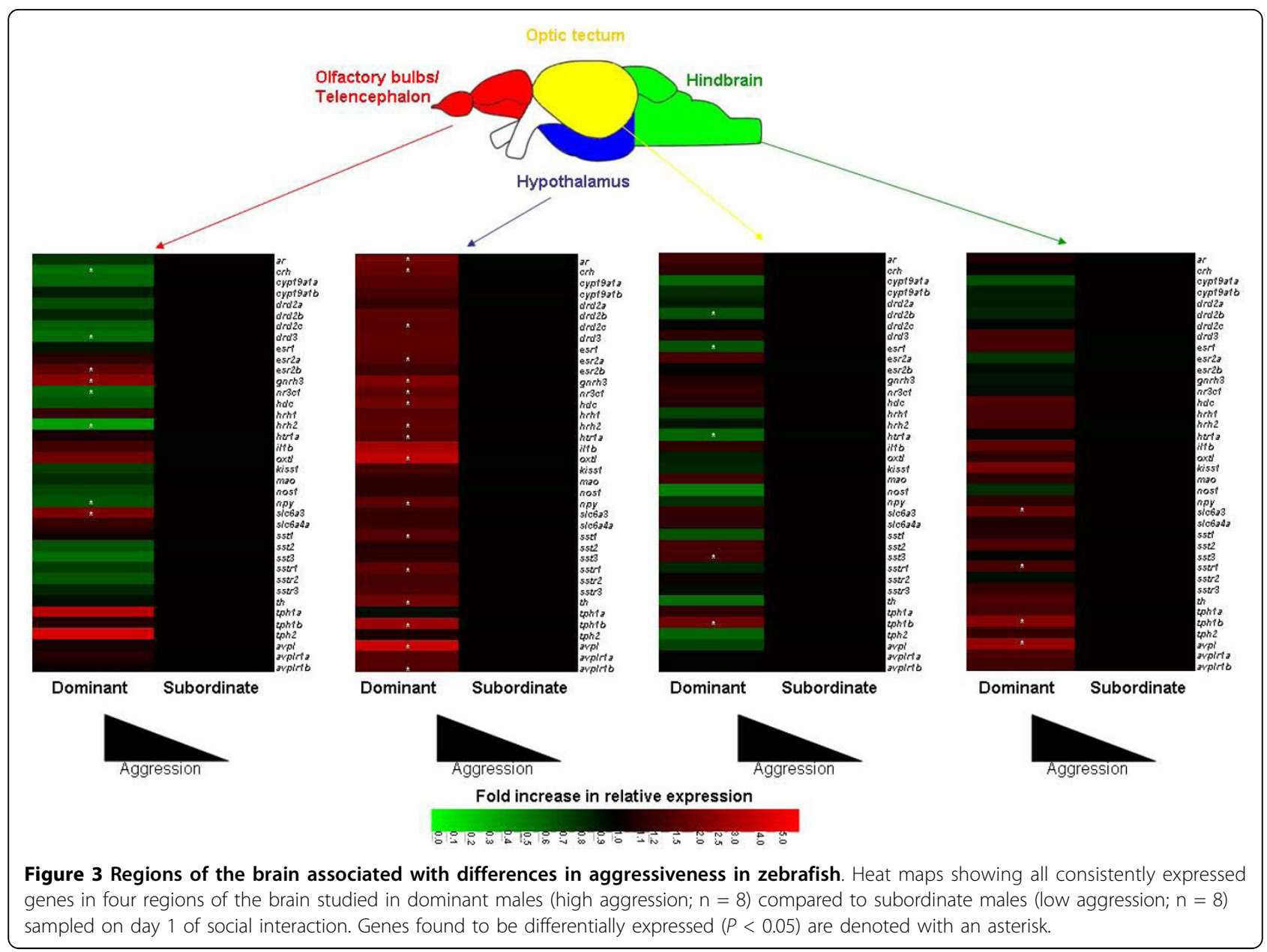

We observed intriguing differences in the direction of regulation (i.e. up- or down-regulation) of the differentially-expressed genes for different regions of the brain. In the hypothalamus and hindbrain, all of the genes were overexpressed in dominant individuals (Fig. 3.). In contrast, in the telencephalon and optic tectum, approximately equal numbers of the genes were overexpressed in dominant and subordinate individuals (Fig. 3). Despite the fact that we used a targeted approach, the high number of genes overexpressed in subordinates in the telencephalon is similar to that observed in the analogous region of the brain (the neocortex) in rats. Here, in an array analysis (containing 1178 brain-associated genes), 18 genes were overexpressed in submissive rats but only one gene was overexpressed in dominant rats [30]. The specific genes associated with dominance in the zebrafish varied between brain regions. Only five genes showed the same expression pattern in more than one brain region (gnrh3, slc6a3, sstr1, tph1b, avpl; Fig. 3). In contrast, other genes had opposite patterns of expression according to social rank between different regions of the brain (htr1a, hrh2, crh, nr3c1, npy; Fig. 3). These data highlight that the use of whole brains for investigating the molecular underpinnings of social behaviours (as in previous studies in fish $[31,32]$ ) may lead to inaccurate interpretations. Our work has shown that regional dissection of the brains of zebrafish is a viable approach, even if it may ideally necessitate a higher sample size. Of course, the application of micropunch or laser-capture microdissection technologies to zebrafish would further enhance the anatomical resolution, but these approaches come with additional technical limitations, such as the need for RNA amplification.

\section{Neurological pathways associated with aggression}

Given that we identified the hypothalamus and telencephalon as the regions of the brain where the greatest number of differentially-expressed genes occurred relating to aggressiveness (based on our chosen gene set), these regions were selected for our more focused analyses. The genes differentially expressed in these brain regions relative to social rank, together with their associated functional pathways, are shown in Table 1. This list of genes represented seven functional pathways and 
Table 1 Genes associated $(P<0.05)$ with aggressiveness and representative neurological pathways in male zebrafish, based on analyses performed using data from hypothalamus and telencephalon of dominant (high aggression) and subordinate (low aggression) males sampled on day 1 of interaction

\begin{tabular}{|c|c|c|c|c|c|c|}
\hline $\begin{array}{l}\text { Region of } \\
\text { brain }\end{array}$ & $\begin{array}{l}\text { GenBank } \\
\text { accession no. }\end{array}$ & Gene & Description & Pathway & $\begin{array}{l}\text { Fold-increase in dominants } \\
\text { (mean } \pm \text { SEM) }\end{array}$ & $\begin{array}{l}P \text { - } \\
\text { value }\end{array}$ \\
\hline \multicolumn{7}{|c|}{ Genes overexpressed in dominants } \\
\hline \multirow[t]{17}{*}{ Hypothalamus } & NM_178293 & avpl & arginine vasopressin-like & HNS & $4.31 \pm 1.60$ & 0.038 \\
\hline & XM_695195 & avplrib & arginine vasopressin-like receptor 16 & HNS & $1.56 \pm 0.18$ & 0.020 \\
\hline & NM_178291 & oxtl & oxytocin-like & HNS & $3.77 \pm 1.01$ & 0.023 \\
\hline & NM_001001843 & tphib & tryptophan hydroxylase 16 & $5-\mathrm{HT}$ & $2.98 \pm 0.69$ & 0.017 \\
\hline & EH441641 & htrla & 5-hydroxytryptamine (serotonin) receptor $1 \mathrm{~A}$ & $5-\mathrm{HT}$ & $1.59 \pm 0.21$ & 0.027 \\
\hline & AF435965 & sst1 & somatostatin 1 & Somatostatin & $1.56 \pm 0.21$ & 0.048 \\
\hline & XM_691574 & sstr1 & somatostatin receptor 1 & Somatostatin & $1.67 \pm 0.22$ & 0.019 \\
\hline & AF075384 & th & tyrosine hydroxylase & Dopamine & $1.94 \pm 0.33$ & 0.021 \\
\hline & AY333792 & $d r d 2 c$ & dopamine receptor $d 2 \mathrm{c}$ & Dopamine & $1.58 \pm 0.22$ & 0.044 \\
\hline & EF150846 & $h d c$ & histidine decarboxylase & Histamine & $1.88 \pm 0.17$ & 0.003 \\
\hline & NM_001045338 & hrh2 & histamine receptor h2 & Histamine & $1.73 \pm 0.28$ & 0.046 \\
\hline & NM_001007379 & $\mathrm{crh}$ & corticotropin releasing hormone & $\mathrm{HPI}$ & $1.75 \pm 0.26$ & 0.033 \\
\hline & EF567112 & $n r 3 c 1$ & $\begin{array}{l}\text { nuclear receptor subfamily 3, group C, member } 1 \\
\text { (glucocorticoid receptor) }\end{array}$ & $\mathrm{HPI}$ & $1.66 \pm 0.25$ & 0.035 \\
\hline & NM_131074 & npy & neuropeptide y & $\mathrm{HPI}$ & $1.67 \pm 0.19$ & 0.024 \\
\hline & AJ304429 & gnrh3 & gonadotropin-releasing hormone 3 & HPG & $2.16 \pm 0.34$ & 0.015 \\
\hline & NM_180966 & esr2a & estrogen receptor $2 a$ & HPG & $1.52 \pm 0.18$ & 0.030 \\
\hline & NM_001083123 & ar & androgen receptor & HPG & $1.96 \pm 0.30$ & 0.010 \\
\hline \multirow[t]{3}{*}{ Telencephalon } & NM_131755 & slc6a3 & $\begin{array}{l}\text { solute carrier family } 6 \text { (neurotransmitter transporter, } \\
\text { dopamine), member } 3\end{array}$ & Dopamine & $2.25 \pm 0.45$ & 0.029 \\
\hline & AJ304429 & gnrh3 & gonadotropin-releasing hormone 3 & HPG & $2.37 \pm 0.50$ & 0.025 \\
\hline & AJ414566 & esr2b & estrogen receptor $2 b$ & HPG & $1.63 \pm 0.21$ & 0.045 \\
\hline \multicolumn{7}{|c|}{ Genes overexpressed in subordinates } \\
\hline \multirow[t]{5}{*}{ Telencephalon } & NM_183067 & drd3 & dopamine receptor $d 3$ & Dopamine & $0.56 \pm 0.09$ & 0.041 \\
\hline & NM_001045338 & hrh2 & histamine receptor h2 & Histamine & $0.38 \pm 0.05$ & 0.010 \\
\hline & NM_001007379 & crh & corticotropin releasing hormone & $\mathrm{HPI}$ & $0.56 \pm 0.07$ & 0.044 \\
\hline & EF567112 & $n r 3 c 1$ & $\begin{array}{l}\text { nuclear receptor subfamily 3, group C, member } 1 \\
\text { (glucocorticoid receptor) }\end{array}$ & $\mathrm{HPI}$ & $0.62 \pm 0.05$ & 0.023 \\
\hline & NM_131074 & npy & neuropeptide y & $\mathrm{HPI}$ & $0.68 \pm 0.08$ & 0.029 \\
\hline
\end{tabular}

suggested a multi-factorial control of aggression in zebrafish. This situation would be in accordance with that suggested to occur for aggression in birds and mammals $[33,34]$. It is possible that, given the multiple physiological roles of some of these genes including in wider physiological processes other than behavior, some of these differences observed in gene expression levels according to social status may relate to other physiological differences between dominant and subordinate zebrafish, for example, in motor function, metabolism or reproduction. Nevertheless, the commonality of the pathways and genes identified in the zebrafish suggests a high degree of conservation in the control of aggression between fish and mammals and this is a novel finding.
Interestingly, the differences in expression of the various genes studied was relatively low between the behavioural phenotypes (for the majority of genes, below 2fold; Table 1). This may indicate that functional of the zebrafish brain with respect to aggressiveness is driven by relatively small differences in individual genes that become of great significance when integrated together into functional gene networks. Of course, it is also possible that there is an amplification of the signals from these relatively small differences in gene expression through post translational events. Other studies on gene expression in the brain have shown that profound differences in phenotype are often associated with only small changes in gene expression [12]. The relatively low level 
changes in gene expression in the brain is, in part, suggested to be the result of a tight homeostatic control in the nervous system [12].

avpl (arginine vasopressin-like) showed the greatest difference in expression between dominant and subordinate males (4.3-fold overexpression in dominant males; Table 1). This was consistent with an observation based on a microarray analysis (with $3.6 \mathrm{~K}$ unique sequences) of whole brains in the cichlid fish Astatotilapia burtoni [32] and provides strong support for a role of this peptide in aggression in the zebrafish. The product of the avpl gene, arginine vasotocin (AVT), and its mammalian homologue arginine vasopressin (AVP), have well established roles in aggression and social position across vertebrate taxa [35]. To test this hypothesis in our zebrafish model, we administered AVT at three doses intraperitoneally (i.p.) to dominant males and observed a highly significant reduction in their aggression (to $7-30 \%$ of sham; paired $t$-tests: $t_{6}=4.568$ and $P=0.004 ; t_{7}=$ 5.227 and $P=0.001 ; t_{8}=7.286$ and $P<0.001$; for $0.5,1$, and $5 \mu \mathrm{g} / \mathrm{g} . \mathrm{b} . \mathrm{w}$. doses, respectively; Fig. 4A). These inhibitory effects of AVT on aggression in zebrafish contradict those for some other fish species [36,37]. This may be because AVT increases aggression in non-territorial (colonial) species and decreases it in territorial species [35], however. Even within a single species, AVT can have opposite effects between behavioural phenotypes; AVT increases aggression in non-territorial males but decreases aggression in territorial males [38]. This may also be the case in zebrafish, with AVT having an opposite effect on dominant (territorial) versus subordinate (non-territorial) individuals and this should be a focus for future studies on the role of AVT in aggression in zebrafish.

Interestingly, of the two genes we quantified encoding AVT's receptors, only avplr1b was differentially expressed between dominant and subordinate males (Table 1 ). In rodents, the $1 \mathrm{~b}$ receptor plays a key role in regulating the actions of AVT on aggression [39]. However, the role of this receptor in aggression has, to date, not been studied in non-mammalian vertebrates. We were unable to source a receptor agonist/antagonist specific to the $1 \mathrm{~b}$ receptor to test for functionality in zebrafish. We were able to test for an effect of the 1a receptor using the specific AVT 1a receptor antagonist Manning compound, however. Following i.p. injection of Manning compound into dominant males we observed no significant difference in aggression (paired $t$-test: $t_{7}=$ 1.762; $P=0.121$; Fig. 4A). The dose of Manning compound we adopted for this work in zebrafish has been shown to inhibit aggression in some other fish species $[37,38]$, although not in all [40].

We also observed oxtl (oxytocin-like), which encodes isotocin (the fish homologue of oxytocin), to be overexpressed in dominant males (Table 1). Isotocin has been shown to have no effect on aggression, and even stimulated sociality, in other fish species $[37,41]$. This is a response well established for oxytocin in mammals [42]. Nevertheless, it is believed that oxytocin's prosocial role (particularly in pair-bond formation) could stimulate aggression towards intruders for the purpose of maintaining monogamy [43], as shown in female Wistar rats [44] and mandarin voles [45].

Within the 5-HT pathway, the genes encoding 5-HT's synthesising enzyme $(t p h)$ and one of its receptors (htrla) were overexpressed in dominant versus subordinate males (3-fold and 1.6-fold, respectively; Table 1 ). To test for a possible role for 5-HT in aggression in zebrafish (as found in birds and mammals), we manipulated the 5-HT system of dominant males using fluoxetine and WAY100,635. Fluoxetine increases synaptic 5-HT levels by blocking its reuptake via the 5-HT transporter (SERT), and WAY100,635 is an antagonist of the $\mathrm{HTR}_{1 \mathrm{~A}}$. Counts of aggression in dominant males decreased to $66-79 \%$ of the sham-treated level following fluoxetine treatment (Fig. 4B). However, these apparent suppressions were not statistically significant (paired $t$ tests: $t_{4}=1.118$ and $P=0.326$; and $t_{5}=2.371$ and $P=$ 0.064 , respectively for the 3 and $4.5 \mu \mathrm{g} / \mathrm{L}$ concentrations). This lack of effect of fluoxetine may relate to our choice of a 1 hour exposure duration (to enable the behavioural observations to be undertaken in the morning when levels of aggression are highest in zebrafish [24]) rather than for the longer duration of 3 hours that has been shown to decrease aggression in a previous study on Betta splendens [46]. Males exposed to WAY100,635, in contrast, showed greater aggression (3.6-fold; paired $t$-test: $t_{7}=-2.643 ; P=0.033$; Fig. 4B). These findings of the pharmacological manipulations are consistent with an inhibitory role for 5-HT in aggression in zebrafish, as implied in studies with these compounds in other fish [46-48].

These results of our pharmacological manipulations of the HNS and 5-HT systems strongly support a utility of gene expression profiling for predicting neurological pathways regulating aggression in the zebrafish. Not all gene responses conformed to the functional responses, however. We might, for example, have expected that in the less aggressive subordinate males there would have been an increased expression of HNS and 5-HT pathway genes to inhibit their aggression (to comply with the inhibitory roles of AVT and 5-HT demonstrated through the manipulations), but this was not the case. Also, expression levels of sst1, encoding the somatostatin peptide, and sstr1, encoding one of its receptors, were higher in dominant males (Table 1) but somatostatin inhibited aggression in the fish $A$. burtoni [49]. We are unable to explain these discrepancies at this time. 


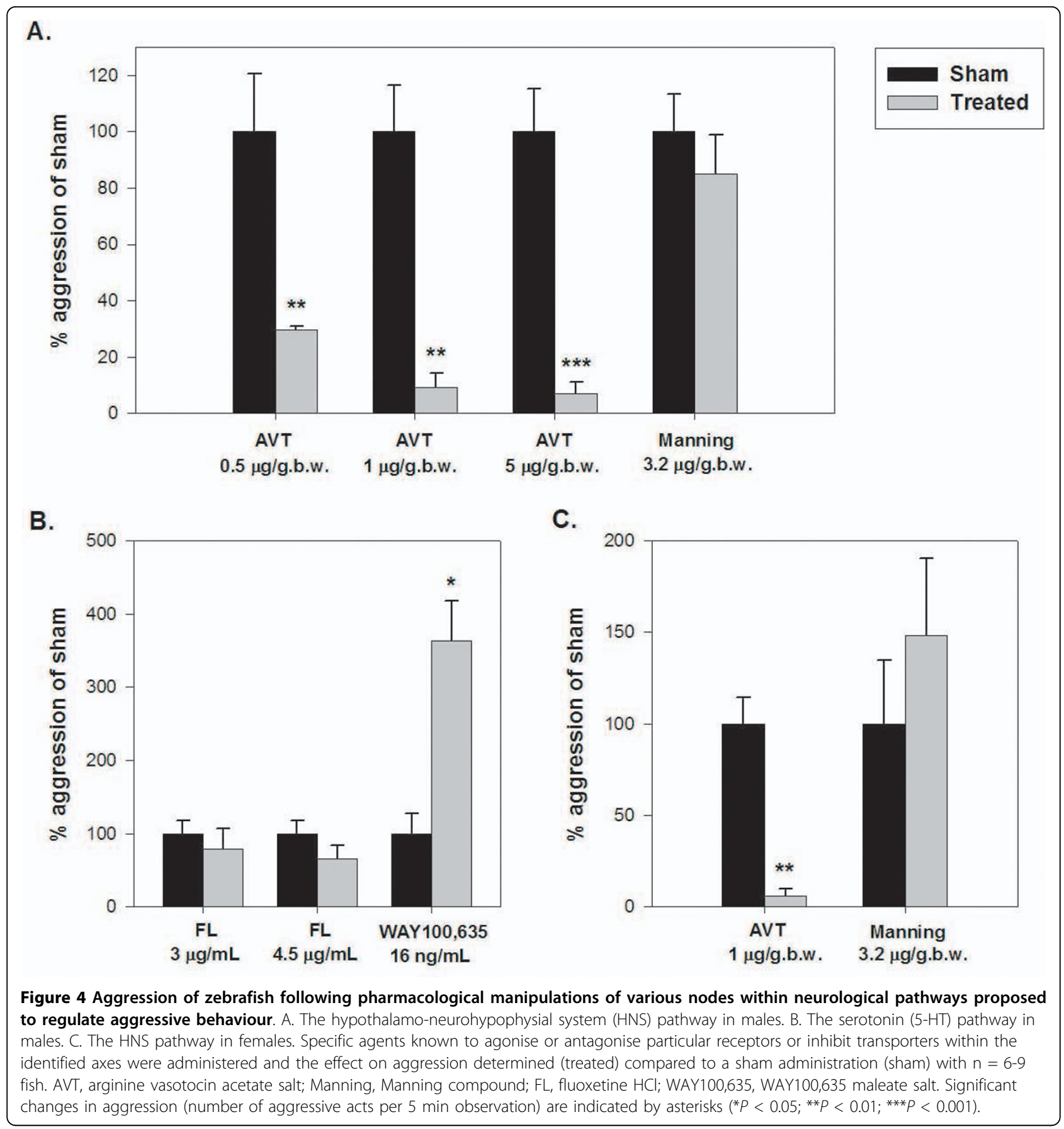

Analyses of the protein levels of the target gene products (e.g. TPH) and/or transcript or protein localisation studies, via in situ hybridisation or immunohistochemical methodologies, may give possible further insight into this in the future. Alternatively, some neurotransmitters are known to have complex and multiple roles, with both stimulatory and inhibitory effects on aggression in the same species. For example, in mammals, 5HT (which normally inhibits aggression) is actually released during initial aggression in individuals that subsequently become dominant, but at this time it loses its inhibitory function $[50,51]$.

Enhanced expression of two dopamine pathway genes (th and slc6a3, which encode the enzyme tyrosine hydroxylase and the dopamine transporter (DAT), responsible for dopamine synthesis and re-uptake, respectively, the latter of which ultimately terminates dopaminergic activity), were associated with higher 
aggression (Table 1). This is a novel finding for fish and is consistent with the stimulatory role of dopamine, and its associated genes, in aggression and dominance in mammals [52-54]. In contrast to th and slc6a3, drd3 was overexpressed in subordinates (Table 1). This finding was consistent with that occurring in the analogous region of the brain in rats [30] and another new finding in non-mammalian vertebrates. In mammals, the D3 receptor, which is highly expressed in limbic areas of the brain, functions in motor behaviour and emotional reactivity (e.g. escape) within social situations [55]. The D2 receptor is known to play a key role in modulating the stimulatory effects of dopamine on aggression in mammals [54]. Our data, therefore, suggest opposing behavioural effects of the D3 and D2 receptors, as proposed in mammals [56].

In the HPG axis, we observed elevated expression of the genes encoding the androgen receptor (AR) and estrogen receptor (ER) $\beta$ subtypes (ar, esr $2 a$, esr $2 b$ ) in dominant males (Table 1). This supports an enhanced responsiveness of the brains of dominant fish to sex steroids, which have stimulatory roles in aggression/ dominance [57]. In mammals, ER $\alpha$ is the candidate ER for mediating the actions of estrogens (and androgens, following aromatisation) on aggression $[58,59]$. ER $\beta$ instead may inhibit aggression [60]. Upstream in this pathway, gnrh3 (the protein product of which stimulates sex steroid production) had 2.2-2.4-fold greater expression in dominant males compared with subordinates (Table 1). This difference is analogous to findings in $A$. burtoni [61], but is perhaps surprising given that a subordinate rank does not prevent reproduction in zebrafish [23,24], as in that species.

In the histamine pathway, we observed overexpression of the genes encoding the histamine-producing enzyme L-histamine decarboxylase $(h d c)$ and the $\mathrm{H}_{2}$ receptor (hrh2) in dominant males (Table 1). Histamine has been shown to modulate other behaviours in the zebrafish $[62,63]$. However, a possible role for histamine in aggression has not yet been put forward in zebrafish, or indeed in any non-mammalian vertebrate, so this is another novel finding. In mammals, histamine facilitates aggression, via $\mathrm{H}_{1}$ receptors, probably by inhibiting 5HT $[64,65]$.

In the HPI axis (homologous to the HPA axis in mammals), crh, $n r 3 c 1$ (formerly known as glucocorticoid receptor), and npy expression were associated with aggressiveness. However, these genes had opposite expression profiles in the hypothalamus compared with the telencephalon (Table 1). All individuals show a stress response upon social interaction [51]. However, a lower stress responsiveness has been associated with an increased likelihood of individuals becoming dominant [66] and, in humans, with high levels and/or abnormal forms of aggression [67]. Corticosteroids, which remain elevated long-term in subordinates, suppress aggression via elevation of brain 5-HT [68]. The overexpression we observed for crh and npy in the telencephalon of subordinate males likely represents an enhanced stress response in these fish compared with dominants. This is because these peptides from the POA in this region ultimately induce corticosteroid release. Both $\mathrm{CRH}$ and NPY influence aggression in mammals [18,69-71] and/ or fish [72], although the effects of $\mathrm{CRH}$ varied depending on the dose given and the region of the brain to which it was administered. This may explain the spatial differences we observed in crh expression.

\section{Sex-related differences in genes associated with aggression}

Female zebrafish, as well as male, show territorial aggression [24]. A further dimension to our analyses was, therefore, the assessment of possible sex-related differences in neuroregulatory pathways of aggression using females sampled on the same days as the males. Little study has been carried out in this regard, which is surprising given that female aggression, including territorial aggression, is frequently encountered in animals and is an important component of mating and social systems $[73,74]$. The ability to study social rank in both sexes, and thus partition the effects of aggression and sex, is a powerful experimental feature of the zebrafish model system. The zebrafish is also of particular interest for comparative studies on sex differences in vertebrates due to the absence of a defined sex determination mechanism (e.g. SRY) or discernible sex chromosomes.

To probe for the main neurological determinants of aggression in zebrafish, based on expression of the targeted genes, we analysed our entire dataset (both males and females for all consistently-expressed genes) using hierarchical clustering and principal component analysis (PCA). The clustering demonstrated that in the hypothalamus, social rank (and, consequently, aggressiveness) was a greater determinant of the expression of the chosen gene set than sex (Fig. 5Ai). In telencephalon, similarly, subordinate males were grouped with subordinate females, rather than with dominant males (Fig. 5Aii). These results were further supported by the PCAs, which generally grouped individual fish according to social rank rather than sex, identifying clear differences between ranks in both regions of the brain, albeit this was most clearly the case in the hypothalamus (Fig. 5Aiii-iv). These data suggest that similar expression profiles may regulate aggression between sexes in zebrafish. In fact, we identified 27 genes in the hypothalamus and 4 genes in the telencephalon that were differentially expressed according to social rank (i.e. always higher in dominants or in subordinates, irrespective of sex; Fig. 


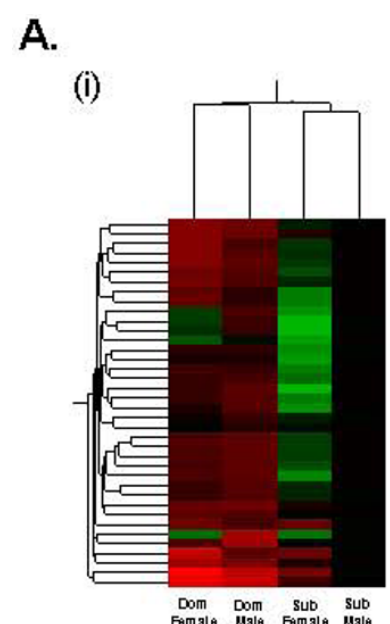

(iii)

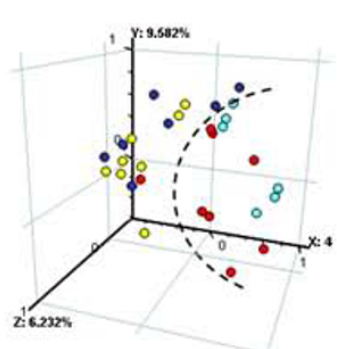

(ii)

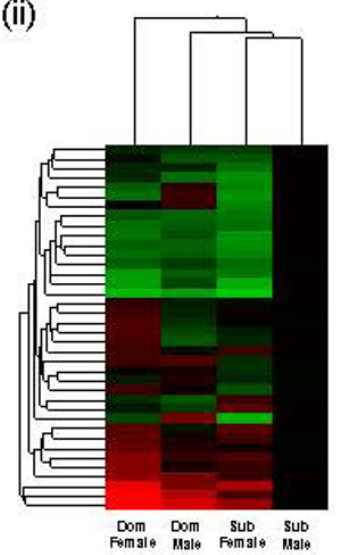

(iv)

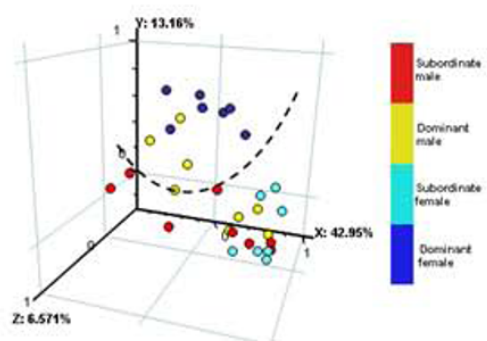

B.

(i)

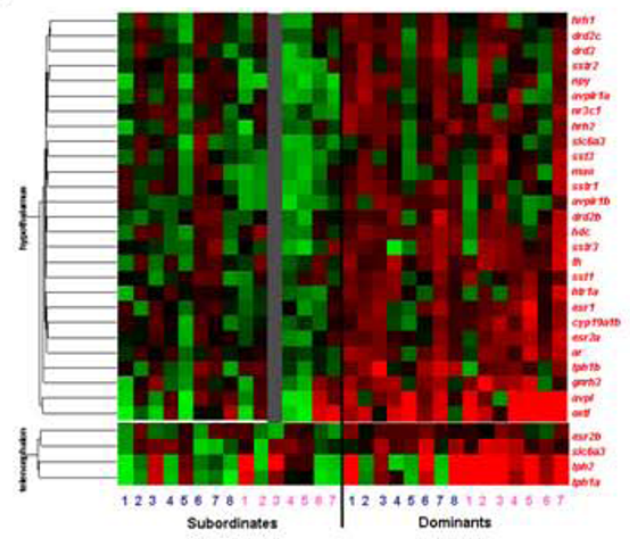

(ii)

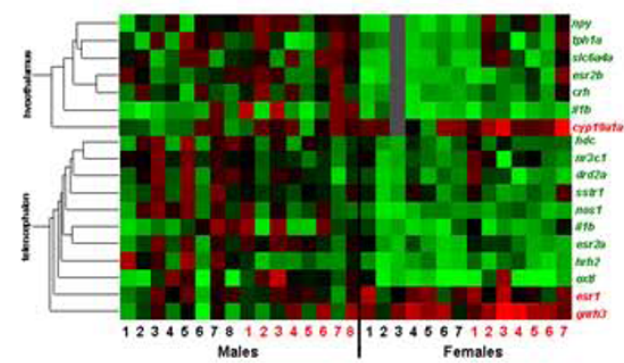

Figure 5 Comparisons of the roles of sex and social rank as determinants of the brain gene expression profiles. A. Hierarchical cluster analysis of all consistently expressed genes in (i) hypothalamus and (ii) telencephalon of dominant (high aggression) and subordinate (low aggression) males and females ( $n=7-8$ fish per group) and the corresponding PCAs performed on the profiles of the same individual fish in (iii) hypothalamus and (iv) telencephalon) (the dashed lines were drawn arbitrarily to aid the visualisation of clustering of the samples). B. Hierarchical cluster analysis of genes identified as differentially expressed $(P<0.05)$ between (i) dominants (high aggression) and subordinates (low aggression) irrespective of their sex, and (ii) between males and females irrespective of their social rank. Fish are shown individually. In (i), individual male fish are indicated by numbers in blue and individual female fish by numbers in pink (all genes were overexpressed in dominant fish). In (ii), individual dominant fish are indicated by numbers in red and individual subordinate fish by numbers in black. In (i)-(ii), genes shown in red were overexpressed in females while genes shown in green were overexpressed in males. Grey colouration indicates no data.

5Bi) but only 5-8 genes differentially expressed according to sex (i.e. always higher in males or in females, irrespective of rank) in these brain regions, respectively (Fig. $5 \mathrm{Bii})$.

28 genes were differentially expressed between ranks in females (Table 2). This greater number of genes compared with that in males was surprising given the lower counts of aggressive behaviours recorded for this sex (Fig. 2). Nevertheless, within the sexes, dominants were similarly more aggressive than subordinates (9- and 7fold in males and females, respectively) (Fig. 2). In females, the greatest number of differentially expressed genes occurred in the hypothalamus (21 genes; Table 2), and these genes belonged to the same neurological pathways observed in males, indicating conservatism in the control of aggression between the sexes in zebrafish. In females, the genes that showed the greatest difference between dominants and subordinates were tph1a, npy and $a v p l$, all of which were more highly expressed in dominants (Table 2). 14 genes were up- or down-regulated in both dominant males and females compared to subordinates in at least one brain region (avpl, avplr1b, oxtl, th, sst1, htr1a, hrh2, nr3c1, crh, gnrh3, esr2a and ar in hypothalamus, and esr $2 b$, slc6a3 and gnrh3 in telencephalon; Tables 1, 2).

Increased expression of $a v p l$ and $a v p l r 1 b$, and $a v p l$ being one of the genes most associated with aggression in females, as occurred in males, is a particularly interesting finding as AVT is best known for its roles in male-specific behaviours [35] and males often have greater numbers/size of AVT neurons [74,75]. Consistent with our results, however, $a v p l$ was shown to be differentially expressed between social ranks in both sexes in Neolamprologus pulcher [76] and, in mice, 
Table 2 Genes associated $(P<0.05)$ with aggressiveness in female zebrafish, based on analyses performed using data from the hypothalamus and telencephalon of dominant (high aggression) and subordinate (low aggression) females sampled on day 1 of interaction

\begin{tabular}{|c|c|c|c|c|c|c|}
\hline $\begin{array}{l}\text { Region of } \\
\text { brain }\end{array}$ & $\begin{array}{l}\text { GenBank } \\
\text { accession no. }\end{array}$ & Gene & Description & Pathway & $\begin{array}{l}\text { Fold-increase in } \\
\text { dominants (mean } \pm \text { SEM) }\end{array}$ & $\begin{array}{l}P \text { - } \\
\text { value }\end{array}$ \\
\hline \multicolumn{7}{|c|}{ Genes overexpressed in dominants } \\
\hline \multirow[t]{21}{*}{ Hypothalamus } & NM_178293 & avpl & arginine vasopressin-like & HNS & $3.89 \pm 0.82$ & 0.014 \\
\hline & XM_695195 & avplr1b & arginine vasopressin-like receptor 16 & HNS & $3.04 \pm 0.82$ & 0.022 \\
\hline & NM_178291 & oxtl & oxytocin-like & HNS & $3.19 \pm 0.58$ & 0.016 \\
\hline & NM_214795 & $\operatorname{tph} 2$ & tryptophan hydroxylase 2 & $5-\mathrm{HT}$ & $2.83 \pm 0.46$ & 0.005 \\
\hline & $\mathrm{EH} 441641$ & htrla & 5-hydroxytryptamine (serotonin) receptor $1 \mathrm{~A}$ & $5-\mathrm{HT}$ & $2.89 \pm 0.72$ & 0.037 \\
\hline & DQ285098 & slc6a4a & $\begin{array}{l}\text { solute carrier family } 6 \text { (neurotransmitter transporter, } \\
\text { serotonin), member } 4 a\end{array}$ & $5-\mathrm{HT}$ & $3.44 \pm 0.57$ & 0.001 \\
\hline & NM_212827 & maoa & monoamine oxidase a & $5-\mathrm{HT}$ & $3.52 \pm 0.82$ & 0.014 \\
\hline & AF435965 & sst 1 & somatostatin 1 & Somatostatin & $1.77 \pm 0.28$ & 0.042 \\
\hline & $\mathrm{B} 1473045$ & sst3 & somatostatin 3 & Somatostatin & $3.61 \pm 1.00$ & 0.002 \\
\hline & AF075384 & th & tyrosine hydroxylase & Dopamine & $2.10 \pm 0.40$ & 0.038 \\
\hline & NM_131755 & slc6a3 & $\begin{array}{l}\text { solute carrier family } 6 \text { (neurotransmitter transporter, } \\
\text { dopamine), member } 3\end{array}$ & Dopamine & $2.56 \pm 0.56$ & 0.030 \\
\hline & NM_001045338 & hrh2 & histamine receptor h2 & Histamine & $1.96 \pm 0.30$ & 0.029 \\
\hline & NM_131660 & nos1 & nitric oxide synthase 1 (neuronal) & Nitric oxide & $2.51 \pm 0.51$ & 0.022 \\
\hline & NM_001007379 & crh & corticotropin releasing hormone & $\mathrm{HPI}$ & $1.88 \pm 0.29$ & 0.025 \\
\hline & EF567112 & $n r 3 c 1$ & $\begin{array}{l}\text { nuclear receptor subfamily 3, group C, member } 1 \\
\text { (glucocorticoid receptor) }\end{array}$ & $\mathrm{HPI}$ & $2.02 \pm 0.38$ & 0.040 \\
\hline & NM_131074 & npy & neuropeptide y & $\mathrm{HPI}$ & $4.37 \pm 0.95$ & 0.002 \\
\hline & AJ304429 & gnrh3 & gonadotropin-releasing hormone 3 & $\mathrm{HPG}$ & $2.78 \pm 0.67$ & 0.044 \\
\hline & NM_131642 & cyp19a1b & $\begin{array}{l}\text { cytochrome P450, family } 19 \text {, subfamily A, } \\
\text { polypeptide } 16\end{array}$ & $\mathrm{HPG}$ & $2.95 \pm 0.57$ & 0.001 \\
\hline & AB037185 & esrl & estrogen receptor 1 & $\mathrm{HPG}$ & $3.02 \pm 0.80$ & 0.005 \\
\hline & NM_180966 & esr2a & estrogen receptor $2 a$ & $\mathrm{HPG}$ & $2.80 \pm 0.55$ & 0.022 \\
\hline & NM_001083123 & ar & androgen receptor & $\mathrm{HPG}$ & $2.61 \pm 0.52$ & 0.014 \\
\hline \multirow[t]{7}{*}{ Telencephalon } & XM_695195 & avplrib & arginine vasopressin-like receptor 16 & HNS & $1.80 \pm 0.22$ & 0.031 \\
\hline & AF548566 & tphla & tryptophan hydroxylase 1a & $5-\mathrm{HT}$ & $4.61 \pm 0.74$ & 0.001 \\
\hline & NM_214795 & $\operatorname{tph} 2$ & tryptophan hydroxylase 2 & $5-\mathrm{HT}$ & $3.09 \pm 0.55$ & 0.016 \\
\hline & $\mathrm{B} 1473045$ & sst3 & somatostatin 3 & Somatostatin & $1.92 \pm 0.33$ & 0.029 \\
\hline & NM_131755 & slc6a3 & $\begin{array}{l}\text { solute carrier family } 6 \text { (neurotransmitter transporter, } \\
\text { dopamine), member } 3\end{array}$ & Dopamine & $2.48 \pm 0.48$ & 0.017 \\
\hline & AJ304429 & gnrh3 & gonadotropin-releasing hormone 3 & $\mathrm{HPG}$ & $1.87 \pm 0.35$ & 0.048 \\
\hline & AJ414566 & $e s r 2 b$ & estrogen receptor $2 b$ & HPG & $1.79 \pm 0.27$ & 0.029 \\
\hline
\end{tabular}

deletion of the gene for the AVP receptor $1 \mathrm{~b}$ suppressed aggression in both sexes [77,78]. To test whether AVT also regulates aggression in females, we repeated our manipulations with AVT and Manning compound in females and found identical effects as observed in males. Injection of dominant females with AVT decreased their aggression to $6 \%$ of the sham level (paired $t$-test: $t_{5}=$ 6.170; $P=0.002)$ while Manning compound had no effect (paired $t$-test: $\left.t_{7}=-0.264 ; P=0.799\right)$ (Fig. 4C).

We did observe some differences in the expression of genes associated with dominance between the sexes (Tables 1,2), including an association of some genes with aggression in females only (tph1a, tph 2 , sst 3 , slc6a4a, slc6a3, nos1, mao, cyp19a1b, esr1), and some in males only (tph1b, sstr1, $d r d 2 c)$. Our results for the tph genes suggest a sex-related difference in the subtypes of the 5-HT synthesising enzyme TPH that may regulate aggression, with the situation in females being more analogous to that in humans [79]. The result for esr 1 was also interesting given that in mice ER $\alpha$ deletion had opposite effects on aggression between sexes $[59,80]$. In relation to nos 1 , in mammals neural nitric oxide (the gas product of which acts as a neurotransmitter [81]) inhibits aggression in males [82] but stimulates 
aggression in females $[18,83]$, again showing conformity in the findings for different sexes in the zebrafish compared with in mammals.

\section{Temporal changes in gene expression associated with changes in aggression}

To identify temporal variation in the genes associated with aggression, we compared our data for fish sampled on day 1 of the social interaction experiment with those for equivalent fish sampled after 5 days (Fig. 6). The number of genes differentially expressed according to rank across the two brain regions altered with time, but differed between sexes (Fig. 6Ai). In males, the number of differentially-expressed genes increased from 20 genes on day 1 to 33 genes on day 5 (Fig. 6Ai). The expression levels of 14 genes were reduced in subordinates and 5 genes increased in dominants over this time (Fig. 6Aii; also see Additional Files 2 and 3). In females, however, the number of differentially expressed genes decreased from 28 genes to 5 (Fig. 6Ai). The expression levels of
20 genes increased in subordinates over the 5 days and of 9 genes reduced in dominants (Fig. 6Aii; also see Additional Files 2 and 3). These changes in gene expression aligned closely with phenotypic-level behavioural changes observed in these fish (Fig. 6Aiii). In males, the level of aggressiveness of the dominant male compared with the subordinate increased from 6.5 -fold to 12 -fold between day 1 and day 5, respectively (Fig. 6Aiii), matching the increased divergence observed in their gene expression profiles. In contrast, in females, the aggressiveness of the dominant female towards the subordinate decreased from 25-fold higher to 5-fold higher (Fig. 6Aiii) and aggression by the subordinate increased substantially (by 11 -fold) over this time (Mann-Whitney rank sum test; $t_{14}$ $=36 ; P=0.021$ ). Again these changes in behaviour of the female zebrafish aligned well with the patterns of gene expression with the reduction in differences (number of differentially expressed genes) observed between female ranks and increased expression of many 'aggression' genes in the hypothalamus in subordinate females.

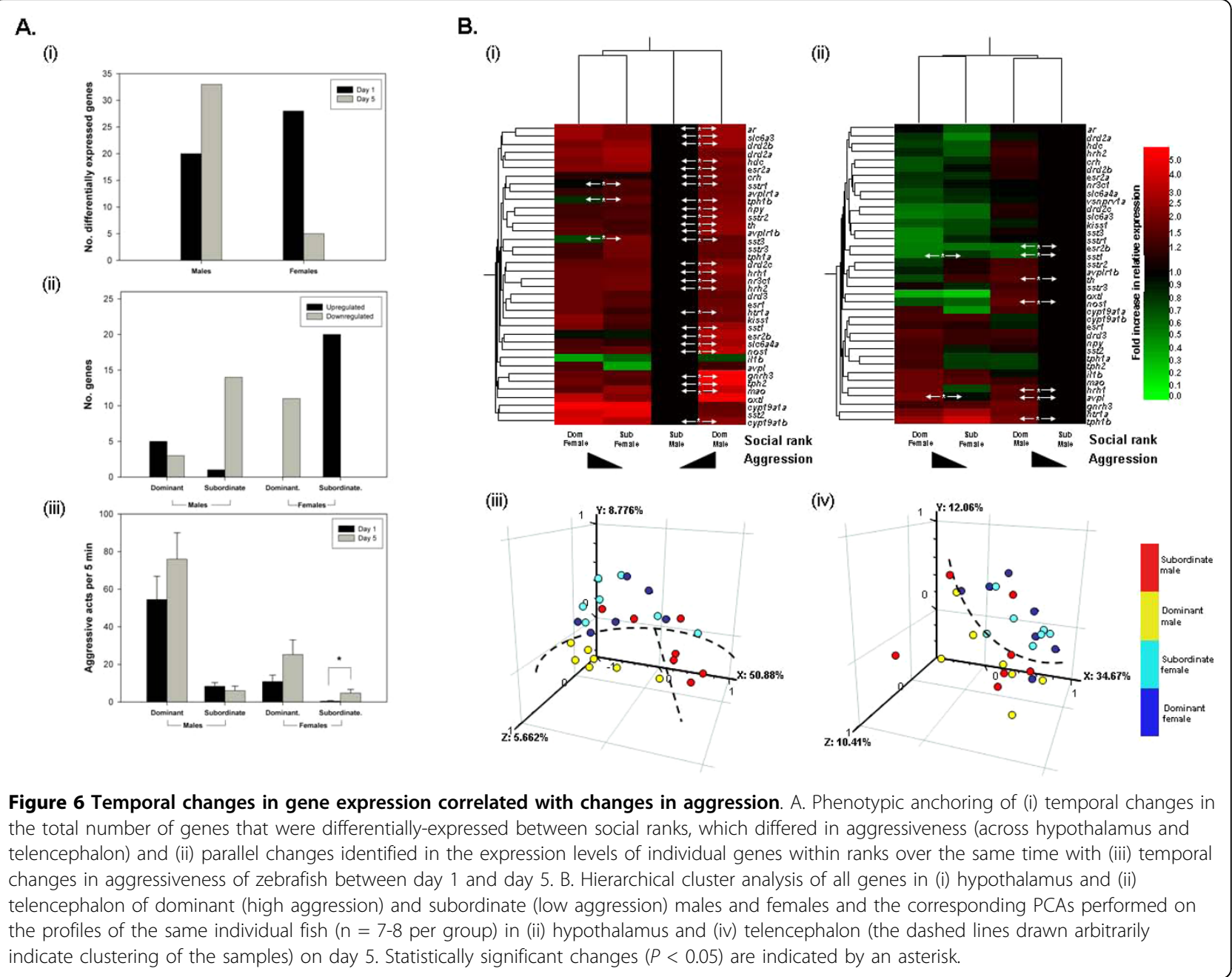


The individual genes differentially expressed between dominant and subordinate fish on day 5 are shown in Fig. 6Bi-ii. When we compared these results with those for day 1 (Table 1), we found that in the hypothalamus of males (Fig. 6Bi), 88\% of the genes overexpressed in dominants on day 1 were also overexpressed on day 5: only the overexpressions of $a v p l$ and oxtl were specific to dominants in day 1 , although 11 genes were specific to dominant males on day 5 (tph2, sst3, sstr 2 , slc6a4a, slc6a3, nos 1, mao, hrh1, esr $2 b, d r d 2 b$, cyp19a1b). In males (Fig. 6Bii), however, the genes differentially expressed between the dominants and subordinates in the telecephalon on day 5 were entirely different to those on day 1. Similarly, in females, none of the genes that were differentially expressed on day 1 were also differentially expressed in the same direction on day 5 (with the exception of sst 3 which was regulated in an opposite direction on the two days (Fig. 6Bi-ii)). avpl and sst 1 in the telencephalon were the only genes that showed the same patterns of expression in dominants versus subordinates in both sexes on day 5 . When the data for both sampling days were combined, only esr 1 was differentially expressed between social ranks in females. This may be a strong candidate for further studies on sex differences in the control of aggression in zebrafish.

Hierarchical clustering and PCAs of these data on day 5 (Fig. 6B), analogous to those performed on the data for day 1 (Fig. 5A), demonstrated that social rank was no longer the main determinant of the expression of the study gene set; rather sex was more important. In the cluster analyses (Fig. 6Bi-ii), the similarity in the gene expression profiles of the dominant and subordinate females (particularly in the hypothalamus) resulted in their placement together in a single condition cluster, rather than with the males of the same social ranks. Similarly, the PCAs (Fig. 6Biii-iv) did not identify any distinct differences between the dominant and subordinate females, thus grouped individuals according to sex. In the hypothalamus (Fig. 6Biii) clear differences were, nonetheless, identified between the dominant and subordinate males. Additionally, the individual males appeared more segregated by rank than observed on day 1 (Fig. 5iii), again aligning with the increased differential in aggression between male ranks by day 5 .

\section{Conclusions}

Aggression is an evolutionary conserved behaviour with implications for human and animal societies and unravelling its neurophysiological basis has many potential benefits. We identified numerous, including novel, candidate neurological genes and pathways associated with aggression in fish, including those possibly conferring sex related differences. For some of these pathways, we further directly linked the pathways with functional responses, albeit our manipulation experiments were limited and we did not, for example, include any determination of dose/concentration-responses. The conservation of many aspects of aggression neurophysiology in zebrafish and mammals supports the use of this fish model in aggression research generally. Further work on aggression using the zebrafish model should establish whether different forms of aggression, the same forms of aggression in different social contexts, and aggression by dominant/territorial compared to subordinate/nonterritorial fish are regulated by similar mechanisms. Additionally, further work needs to investigate the inter linkages between aggression control pathways and develop a greater understanding of sex related differences.

\section{Methods \\ Zebrafish stocks}

The zebrafish used were bred in-house from the Wild Indian Karyotype (WIK) strain. Fish were maintained at $28 \pm 1^{\circ} \mathrm{C}$ with a constant photoperiod of $12 \mathrm{~h}$ light: $12 \mathrm{~h}$ dark (08.30-20.30) and an artificial dawn/dusk transition of $30 \mathrm{~min}$. The tank water was reconstituted reverse osmosis-filtered mains water supplied on a flow-through system ( $2 \mathrm{~L} /$ hour). Prior to the experiments, fish were maintained in large mixed-sex holding tanks. The experimental tanks used were $300 \mathrm{~mm} \times 300 \mathrm{~mm} \times 300$ $\mathrm{mm}$ with a working volume of $18 \mathrm{~L}$ and contained a central spawning site, consisting of glass marbles with an artificial weed. Opaque dividers prevented visual interactions between fish in neighbouring tanks. Fish were fed to satiation twice daily with freshly hatched Artemia nauplii (ZM Ltd., Hampshire, UK) and TetraMin tropical flake food (Tetra Werke, Melle, Germany). All animal-use procedures were carried out ethically according to UK Home Office guidelines.

\section{Social interaction study: experiment design and sampling} Immediately prior to the artificial dusk on day zero, 64 fish (32 males and 32 females) were assigned randomly into 16 experimental tanks, with two males and two females per tank, and the fish were allowed to acclimate overnight (such that the fish recovered from any handling stress encountered, resumed 'normal' behaviour and developed a dominance hierarchy). The following morning, beginning at $08.30 \mathrm{am}, 8$ of the tanks were videotaped for 10 min using an Ikegami ICD-848P digital colour-black/white video camera (Ikegami Co. Ltd., Tsushinki, Japan) coupled to a Sony HDV 1080i digital HD videocassette recorder. Dominance/subordinance was assigned for each fish (based on territoriality - occupation and defence of the spawning site), and the fish were sacrificed by terminal anaesthesia (benzocaine; 
Sigma, UK). Four distinct brain regions - the telencephalon (including the olfactory bulbs and POA), hypothalamus, optic tectum, and hindbrain (medulla oblongata and cerebellum) - were dissected from each fish, snap-frozen in liquid nitrogen, and stored at $-80^{\circ} \mathrm{C}$ until processing. For the remaining 8 tanks, the same procedure was conducted on day 5 of the study. Based on observations of behaviour, a dominant-subordinate relationship formed between the two males and between the two females in all, but one of the colonies. In the exception, no obvious hierarchy developed between the two females, and this colony was, therefore, excluded from further analyses.

\section{Behavioural analyses}

HDV files containing behavioural recordings were streamlined to AV1 files using Adobe Premier, and viewed at half speed with Windows Media Player. Aggressive behaviours ('chase', 'spar', 'repel' [24]) performed by each fish to its dominant/subordinate were counted for $5 \mathrm{~min}$.

\section{RNA extraction and reverse transcription}

RNA was extracted separately from each of the four brain regions of each individual fish using the RNeasy Micro Kit (Qiagen, Crawley, UK), which included a DNase treatment, and RNA quantity/quality was verified by Nanodrop ND-1000 spectrophotometer (Nanodrop Technologies, Inc., Wilmington, DE, USA). For each individual tissue sample (4 per fish, giving a total of 256 samples), cDNA was synthesized from the total amount of RNA obtained (approximately 20-100 ng) using random hexamers (MWG-Biotech, Ebersburg, Germany) and M-MLV reverse transcriptase (Promega, Southampton, UK).

\section{Real-time PCR}

A suite of 40 genes involved in HNS, 5-HT, somatostatin, dopamine, histamine, nitric oxide, HPI axis, and HPG axis pathways were selected for study in zebrafish based on the literature for studies on aggression in mammals (Fig. 1). For several of the target genes (avplr1b, sstr1, sstr2, sstr3), annotated cDNA sequences were not available for zebrafish. For these genes, cDNA sequences were identified by querying the zebrafish genome database with the sequences for these cDNAs in other fish species using the BLAST algorithm. Hits obtained from the BLASTs were then screened for conserved motifs specific to each transcript via multiple sequence alignment (ClustalW). Primers specific for the target genes were designed with Beacon Designer 3.0 (Premier Biosoft International, Palo Alto, CA, USA) and assays optimised and validated for real-time PCR using SYBR Green chemistry, as described previously [84] (also see Additional File 4). Real-time PCR was conducted in triplicate for each individual sample $(n=256)$ on 1:3-diluted cDNA with the iCycler iQ Real-time Detection System (Bio-Rad Laboratories Inc., Hercules, CA) as previously described [84] but with the reaction volume scaled-down to $15 \mu \mathrm{L}$. Relative expression levels (gene of interest: 'housekeeping' gene) were determined using the arithmetic comparative $2^{-\Delta \Delta C t}$ method with efficiency correction as previously described [84]. ribosomal protein L8 ( $r$ l8) was used for relative quantification because its expression was unaffected by social rank, sex, or duration of interaction. For further details of the real-time PCR assays and methodologies used, see Additional File 4.

\section{Pharmacological manipulations}

Pharmacological agents known to manipulate specific nodes within the HNS and 5-HT pathways in fish/mammals were administered to dominant males or females via i.p. injection or immersion (epithelial uptake). For all manipulations, a repeated-measures design was used whereby the same fish were tested under both sham and treated conditions. The order of treatments was randomised for each fish within each experiment. On the morning of the day before the start of each experiment, 24 fish were randomly allocated to 12 tanks with 2 fish per tank and a very small section of caudal fin was removed from one of the fish from each tank to permit identification of individual fish (this procedure did not affect a fish's social rank/behaviour and the tail grew back completely after 7-10 days). That afternoon, social rank was assigned for each fish and the tanks in which the most stable hierarchies had developed were selected for the drug manipulations (minimum $\mathrm{n}=6$, maximum $\mathrm{n}=9$ ). The following morning, the dominant fish from each tank was removed for experimental treatment. When immersion was used as the route of drug delivery, a stock solution of the chemical was prepared in aerated aquarium water and fish exposed to either this (treated) or untreated aquarium water (sham) in a glass beaker (50 mL volume) at $28^{\circ} \mathrm{C}$ for $1 \mathrm{~h}$. When injection was used as the route of drug delivery, the chemical was dissolved in $0.9 \%$ saline and fish injected into the i.p. cavity with either this (treated) or saline alone (sham), using a $0.3 \mathrm{~mL} 30 \mathrm{G}$ needle syringe (BD Micro-Fine U-100 insulin syringe) with a $10 \mu \mathrm{l}$ injection volume. Following a 40 min recovery period for the fish in their respective tanks, behavioural analyses were conducted blind in duplicate. In these analyses, the total number of aggressive acts performed by the dominant fish towards the subordinate was quantified over a period of $5 \mathrm{~min}$. All fish were given 24-48 hours (based on pilot studies) recovery prior to the subsequent treatment within an experiment. For the HNS axis, we tested the natural 
AVT peptide, AVT acetate salt (Sigma V0130), which was administered by i.p. injection at doses of $0.5,1$, and $5 \mu \mathrm{g} / \mathrm{g} . \mathrm{b} . \mathrm{w}$. to males and $1 \mu \mathrm{g} / \mathrm{g}$.b.w. to females, and the specific AVT receptor 1a antagonist Manning compound ( $\left[\beta\right.$-Mercapto- $\beta, \beta$-cyclopentamethylenepropionyl ${ }^{1}$, O-me-Tyr ${ }^{2}, \mathrm{Arg}^{8}$ ]-Vasopressin [85]; Sigma V2255), also administered via i.p. injection but at a dose of $3.2 \mu \mathrm{g} / \mathrm{g}$. b.w. to both males and females. For the 5-HT axis, we tested the $\mathrm{HTR}_{1 \mathrm{~A}}$ antagonist, WAY 100,635 maleate salt (Sigma W108), at a concentration of $16 \mu \mathrm{g} / \mathrm{L}$, and the SERT inhibitor, fluoxetine $\mathrm{HCl}$ (Sigma W108), at concentrations of 3 and $4.5 \mu \mathrm{g} / \mathrm{mL}$, both by immersion to males only. In these studies, the concentrations/doses and experimental designs we used were based on previous studies with these drugs in fish $[37,38,47,86]$. Further details of the pilot studies carried out in developing the methodologies used for the pharmacological manipulations are given in Additional File 5. There were no apparent effects of any of the compounds on the general level of behaviour/locomotion of the fish, which was consistent with the findings of other studies using these compounds in fish (e.g. $[38,46])$ and mammals (e.g. [85]).

\section{Data analysis}

In the social interaction experiment, statistical differences in aggression between social ranks and sexes were tested by two-way ANOVA, followed by Holm-Sidak post hoc test, and between days by $t$-test (or a non-parametric alternative when appropriate) within Sigma Stat 3.10 (Jandel Scientific Software). Real-time PCR data were imported into GeneSpring GX 7.3 Software (Silicon Genetics, USA). All of the 40 study genes were expressed across the different regions of the brain in all fish, with two exceptions (th2, gnrh2) which we subsequently excluded from the analyses. Based on the entire set of samples for the total of 38 consistently expressed genes, genes and groups of samples were clustered following a hierarchical strategy with average linkage. The similarity measure used was Euclidian distance because this takes into account the magnitude of changes in gene expression. PCA was performed to identify the main trends between the gene expression profiles of individual fish. To identify differentially expressed genes, comparisons between social ranks, sexes and time periods were performed by $t$-test followed by multiple testing correction (Benjamini and Hochberg false discovery rate). In the pharmacological manipulations, the effect of each drug on aggression was tested by comparing the total number of aggressive acts between sham and experimental treatment for each fish via paired $t$-test (Sigma Stat 3.10). All differences were considered statistically significant at $P<0.05$.

\section{Additional material}

\begin{abstract}
Additional file 1: Genes associated with aggressiveness in different regions of the brain. Genes associated $(P<0.05)$ with aggressiveness in different regions of the brain in male zebrafish. Analyses were performed using data from dominant and subordinate males sampled on day 1 of aggression.
\end{abstract}

Additional file 2: Changes in the expression of individual genes in hypothalamus and telencephalon in males between day 1 and day $\mathbf{5}$ of the social interaction study. Changes in the expression of individual genes in (A) hypothalamus and (B) telencephalon in males between day 1 and day 5 of the social interaction experiment. Data are represented as means \pm SEM and expressed as the ratio of 'gene of interest':rpL8. Significant differences in expression are denoted by an asterisk $(P<0.05$; $t$-test $)$.

Additional file 3: Changes in the expression of individual genes in hypothalamus and telencephalon in females between day 1 and day $\mathbf{5}$ of the social interaction study. Changes in the expression of individual genes in (A) hypothalamus and (B) telencephalon in females between day 1 and day 5 of the social interaction experiment. Data are represented as means \pm SEM and expressed as the ratio of 'gene of interest':rpL8. Significant differences in expression are denoted by an asterisk $(P<0.05$; $t$-test).

Additional file 4: Further details of the real-time PCR assays and methodologies used. Word DOC displaying further details of the realtime PCR assays and methodologies used.

Additional file 5: Further details of the methodology used in the pharmacological manipulations. Word DOC displaying further details of the methodology used in the pharmacological manipulations.

\section{Acknowledgements}

The authors would like to thank Dr Eduarda Santos, of the University of Exeter, UK, for her advice on the gene expression analysis methods.

\section{Authors' contributions}

AF and GP designed and carried out the social interaction experiment. AF carried out the gene expression analyses, data analyses and drafted the manuscript. GP and TH carried out the behavioural analyses. AF, TH and GP carried out the pharmacological manipulations. CT participated as a supervisor in the design of the studies and analyses, and edited the manuscript. All authors read and approved the final manuscript.

Received: 19 May 2010 Accepted: 16 September 2010

Published: 16 September 2010

\section{References}

1. Blanchard RJ, Wall PM, Blanchard DC: Problems in the study of rodent aggression. Horm Behav 2003, 44:161-170.

2. Sapolsky RM: The influence of social hierarchy on primate health. Science 2005, 308:648-652.

3. Humble F, Berk M: Pharmacological management of aggression and violence. Hum Psychopharmacol 2003, 18:423-436.

4. Martinez M, Blasco-Ros C: Typology of human aggression and its biological control. Novartis Foundation Symposium 2005, 268:201-208.

5. Singh SV, Treadwell J, Kleiber ML, Harrison M, Uddin RK: Analysis of behavior using genetical genomics in mice as a model: from alcohol preferences to gene expression differences. Genome 2007, 50:877-897.

6. Feldker DEM, de Kloet ER, Kruk MR, Datson NA: Large-scale gene expression profiling of discerete brain regions: potential, limitations, and application in genetics of aggressive behavior. Behav Genet 2003, 33:537-548.

7. Alaux C, Sinha S, Hasadsri L, Hunt GJ, Guzmán-Novoa E, DeGrandiHoffman G, Uribe-Rubio JL, Southey BR, Rodriguez-Zas S, Robinson GE: Honey bee aggression supports a link between gene regulation and behavioural evolution. Proc Natl Acad Sci USA 2009, 106:15400-15405. 
8. Meng B, Zhu S, Li S, Zeng Q, Mei B: Global view of the mechanisms of improved learning and memory capability in mice with music-exposure by microarray. Brain Res Bull 2009, 80:36-44.

9. Ellis LL, Carney GE: Drosophila melanogaster males respond differently at the behavioural and genome-wide levels to Drosophila melanogaster and Drosophila simulans females. J Evol Biol 2009, 22:2183-2191.

10. Sequeira A, Mamdani F, Ernst C, Vawter MP, Bunney WE, Lebel V, Rehal S, Klempan T, Gratton A, Benkelfat C, Rouleau GA, Mechawar N, Turecki G: Global brain gene expression analysis links glutamatergic and GABAergic alterations to suicide and major depression. PLoS One 2009, 4 e6585.

11. Webb KJ, Norton WH, Trümbach D, Meijer AH, Ninkovic J, Topp S, Heck D, Marr C, Wurst W, Theis FJ, Spaink HP, Bally-Cuif L: Zebrafish reward mutants reveal novel transcripts mediating the behavioral effects of amphetamine. Genome Biol 2009, 10:R81.

12. Nisenbaum LK: The ultimate chip shot: can microarray technology deliver for neuroscience? Genes Brain Behav 2002, 1:27-34.

13. Feldker DEM, Datson NA, Veenema AH, Meulmeester E, De Kloet ER, Vreugdenhill E: Serial analysis of gene expression predicts structural differences in hippocampus of long attack latency and short attack latency mice. Eur J Neurosci 2003, 17:379-387.

14. Dierick HA, Greenspan RJ: Molecular analysis of flies selected for aggressive behaviour. Nat Genet 2006, 38:1023-1031.

15. Edwards AC, Rollmann SM, Morgan TJ, Mackay TFC: Quantitative genomics of aggressive behaviour in Drosophila melanogaster. PLoS Genet 2006, 2 : e154.

16. Edwards AC, Zwarts L, Yamamoto A, Callaerts P, Mackay TFC: Mutations in many genes affect aggressive behaviour in Drosophila melanogaster. BMC Biol 2009, 7:29.

17. Edwards AC, Ayroles JF, Stone EA, Carbone MA, Lyman RF, Mackay TFC: A transcriptional network associated with natural variation in Drosophila aggressive behavior. Genome Biol 2009, 10:R76.

18. Gammie SC, Auger AP, Jessen HM, Vanzo RJ, Awad TA, Stevenson SA: Altered gene expression in mice selected for high maternal aggression. Genes Brain Behav 2007, 6:432-443.

19. Buitenhuis B, Hedegaard J, Janss L, Sorensen P: Differentially expressed genes for aggressive pecking behaviour in laying hens. BMC Genomics 2009, 10:544.

20. Hsu CH, Wen ZH, Lin CS, Chakraborty C: The zebrafish model: use in studying cellular mechanisms for a spectrum of clinical disease entities. Curr Neurovasc Res 2007, 4:111-120.

21. Gerlai R: Zebra fish: an uncharted behavior genetic model. Behav Genet 2003, 33:461-468.

22. Larson ET, O'Malley DM, Melloni RH Jr: Aggression and vasotocin are associated with dominant-subordinate relationships in zebrafish. Behav Brain Res 2006, 167:94-102.

23. Spence $R$, Jordan WC, Smith C: Genetic analysis of male reproductive success in relation to density in the zebrafish, Danio rerio. Front Zool 2006, 3:5.

24. Paull GC, Filby AL, Giddins HG, Coe TS, Hamilton PB, Tyler CR: Dominance hierarchies in zebrafish (Danio rerio) and their relationship with reproductive success. Zebrafish 2010, 7:109-117.

25. Moretz JA, Martins EP, Robison BD: Behavioral syndromes and the evolution of correlated behavior in zebrafish. Behav Ecol 2007, 18:556-562

26. Filby AL, Paull GC, Bartlett EJ, Van Look KJW, Tyler CR: Physiological and health consequences of social status in zebrafish (Danio rerio). Physiol Behav 2010

27. Ferris CF, Stolberg T, Kulkarni P, Murugavel M, Blanchard R, Blanchard DC, Febo M, Brevard M, Simon NG: Imaging the neural circuitry and chemical control of aggressive motivation. BMC Neurosci 2008, 9:111.

28. Northcutt RG: Evolution of the telencephalon in nonmammals. Ann Rev Neurosci 1981, 4:301-350.

29. Roeling TA, Veening JG, Kruk MR, Peters JP, Vermelis ME, Nieuwenhuys R: Efferent connections of the hypothalamic "aggression area" in the rat. Neuroscience 1994, 59:1001-1024.

30. Kroes RA, Panksepp J, Burgdorf J, Otto NJ, Moskal JR: Modeling depression: social dominance-submission gene expression patterns in rat neocortex. Neuroscience 2006, 137:37-49.

31. Sneddon LU, Margareto J, Cossins AR: The use of transcriptomics to address questions in behaviour: production of a suppression subtractive hybridisation library from dominance hierarchies of rainbow trout. Physiol Biochem Zool 2005, 78:695-705.

32. Renn SCP, Aubin-Horth N, Hofmann HA: Fish and chips: functional genomics of social plasticity in an African cichlid fish. J Exp Biol 2008, 211:3041-3056

33. Miczek KA, Maxson SC, Fish EW, Faccidomo S: Aggressive behavioural phenotypes in mice. Behav Brain Res 2001, 125:167-181.

34. Buitenhuis B, Hedegaard J, Janss L, Sorensen P: Differentially expressed genes for aggressive pecking behaviour in laying hens. BMC Genomics 2009, 10:544.

35. Caldwell HK, Lee $\mathrm{H}-J$, Macbeth AH, Young WS: Vasopressin: behavioural roles of an "original" neuropeptide. Prog Neurobiol 2008, 84:1-24.

36. Lema SC, Nevitt GA: Exogenous vasotocin alters aggression during agonistic exchanges in male Armagosa pupfish (Cyprinodon nevadensis amargosae). Horm Behav 2004, 46:628-637.

37. Santangelo N, Bass A: New insights into neuropeptide modulation of aggression: field studies of arginine vasotocin in a territorial tropical damselfish. Proc R Soc B Biol Sci 2006, 273:3085-3092.

38. Semsar K, Kandel FLM, Godwin J: Manipulations of the AVT system shift social status and related courtship and aggressive behaviour in the bluehead wrasse. Horm Behav 2001, 40:21-31.

39. Caldwell HK, Wersinger SR, Young WS: The role of the vasopressin 1b receptor in aggression and other social behaviours. Prog Brain Res 2008, 170:65-72.

40. Backström T, Winberg S: Arginine-vasotocin influence on aggressive behaviour and dominance in rainbow trout. Physiol Behav 2009, 96:470-475.

41. Thompson RR, Walton JC: Peptide effects on social behavior: effects of vasotocin and isotocin on social approach behaviour in male goldfish (Carassius auratus). Behav Neurosci 2004, 118:620-626.

42. Donaldson ZR, Young LJ: Oxytocin, vasopressin, and the neurogenetics of sociality. Science 2008, 322:900-904

43. Leng G, Meddle SL, Douglas AJ: Oxytocin and the maternal brain. Curr Opin Pharmacol 2008, 8:731-734.

44. Bosch OJ, Meddle SL, Beiderbeck DI, Douglas AJ, Neumann ID: Brain oxytocin correlates with maternal aggression: link to anxiety. J Neurosci 2005, 25:6807-6815.

45. Jia R, Tai FD, An SC, Broders H, Ding XL, Kong Q, Zhao L, Zhang H: Effects of neonatal oxytocin treatment on aggression and neural activities in mandarin voles. Physiol Behav 2008, 95:56-62.

46. Lynn SE, Egar JM, Walker BG, Sperry TS, Ramenofsky M: Fish on Prozac: a simple, noninvasive physiology laboratory investigating the mechanisms of aggressive behaviour in Betta splendens. Advan Physiol Educ 2007, 31:358-363.

47. Perreault H, Semsar K, Godwin J: Fluoxetine treatment decreases territoria aggression in a coral reef fish. Physiol Behav 2003, 79:719-724.

48. Smith GT, Combs N: Serotonergic activation of $5 \mathrm{HT}_{1 \mathrm{~A}}$ and $5 \mathrm{HT}_{2}$ receptors modulate dimorphic communication signals in the weakly electric fish Apteronotus leptorhynchus. Horm Behav 2008, 54:69-82.

49. Trainor BC, Hofmann HA: Somatostatin regulates aggressive behaviour in an African cichlid fish. Endocrinology 2006, 147:5119-5125.

50. van der Vegt BJ, Lieuwes N, Van de Wall EHEM, Kato K, Moya-Albiol L, Martinez-Sanchis S, de Boer SF, Koolhaas JM: Activation of serotonergic neurotransmission during the performance of aggressive behavior in rats. Behav Neurosci 2003, 117:667-674.

51. Summers $\mathrm{CH}$, Winberg S: Interactions between the neural regulation of stress and aggression. J Exp Biol 2006, 209:4581-4589.

52. Filipenko M, Alekseyenko OV, Beilina AG, Kamynina TP, Kudryavtseva NN Increase of tyrosine hydroxylase and dopamine transporter mRNA levels in ventral tegmental area of male mice under influence of repeated aggression experience. Brain Res Mol Brain Res 2001, 96:77-81.

53. Rodriguiz RM, Chu R, Caron MG, Westel WC: Aberrant responses in social interaction of dopamine transporter knockout mice. Behav Brain Res 2004, 148:185-198.

54. Bondar NP, Boyarskikh UA, Kovalenko IL, Filipenko ML, Kudryatseva NN: Molecular implications of repeated aggression: Th, Dat1, Snca and Bdnf gene expression in the VTA of victorious male mice. PLoS one 2009, 4 : e4190.

55. Grendreau PL, Petitto JM, Schnauss R, Frantz KJ, Van Hartesveldt $C_{\text {, }}$ Gariepy $\mathrm{L}$, Lewis $\mathrm{MH}$ : Effects of the putative dopamine $\mathrm{D} 3$ receptor 
antagonist PNU 99194A on motor behaviour and emotional reactivity in C57BL/6J mice. Eur I Pharmacol 1997, 337:147-155.

56. Richtand NM, Woods SC, Berger SP, Strakowski SM: D3 dopamine receptor, behavioural sensitization and psychosis. Neurosci Biobehav Rev 2001, 25:427-443.

57. Burmeister SS, Kailasanath V, Fernald RD: Social dominance regulates androgen and estrogen receptor gene expression. Horm Behav 2007, 51:164-170.

58. Trainor BC, Greiwe KM, Nelson RJ: Individual differences in estrogen receptor $\alpha$ in select brain nuclei are associated with individual differences in aggression. Horm Behav 2006, 50:338-345.

59. Ogawa S, Washburn TF, Taylor J, Lubahn DB: Modifications of testosterone-dependent behaviors by estrogen receptor $\alpha$ gene disruption in male mice. Endocrinol 1998, 139:5058-5069.

60. Nomura M, Andersson S, Korach KS, Gustafsson J-A, Pfaff DW, Ogawa S: Estrogen receptor- $\beta$ gene disruption potentiates estrogen-inducible aggression but not sexual behaviour in male mice. Eur J Neurosci 2006, 23:1860-1868

61. White SA, Nquyen T, Fernald RD: Social regulation of gonadotropinreleasing hormone. J Exp Biol 2002, 205:2567-2581.

62. Peitsaro N, Kaslin J, Anichtchik OV, Panula P: Modulation of the histaminergic system and behaviour by alpha-fluoromethylhistidine in zebrafish. J Neurochem 2003, 86:432-441.

63. Peitsaro N, Sundvik M, Anichtchik OV, Kaslin J, Panula P: Identification of zebrafish histamine $\mathrm{H}_{1}, \mathrm{H}_{2}$ and $\mathrm{H}_{3}$ receptors and effects of histaminergic ligands on behavior. Biochem Pharmacol 2007, 73:1205-1214

64. Onodera K, Yamatodani A, Watanabe T: Effect of alphafluoromethylhistidine on brain histamine and noradrenaline in muricidal rats. Methods Find Exp Clin Pharmacol 1993, 15:423-427.

65. Yanai K, Son LZ, Endou M, Sakurai E, Nakagawasai O, Tadano T, Kisara K, Inoue I, Watanabe T, Watanabe T: Behavioural characterization and amounts of brain monoamines and their metabolites in mice lacking histamine $\mathrm{H} 1$ receptors. Neuroscience 1998, 87:479-487.

66. Overli O, Korzan WJ, Hoglund E, Winberg S, Bollig H, Watt M, Forster GL, Barton BA, Overli E, Renner KJ, Summers CH: Stress coping style predicts aggression and social dominance in rainbow trout. Horm Behav 2004, 45:235-241.

67. McBurnett K, Lahey BB, Rathouz PJ, Loeber R: Low salivary cortisol and persistent aggression in boys referred for disruptive behaviour. Arch Gen Psych 2000, 57:38-43.

68. Vollmayr B, Keck S, Henn FA, Schloss P: Acute stress decreases serotonin transporter mRNA in the raphe pontis but not in other raphe nuclei of the rat. Neurosci Lett 2000, 290:109-112.

69. Tazi A, Dantzer R, Le Moal M, Rivier J, Vale W, Koob GF: Corticotropinreleasing factor antagonist blocks stress-induced fighting in rats. Regul Pept 1987, 18:37-42.

70. Elkabir DR, Wyatt ME, Vellucci SV, Herbert J: The effects of separate or combined infusions of corticotrophin-releasing factor and vasopressin either intraventricularly or into the amygdala on aggressive and investigative behaviour in the rat. Regul Pept 1990, 28:199-214.

71. Karl T, Lin S, Schwarzer C, Sainsbury A, Couzens M, et al: Y1 receptors regulate aggressive behavior by modulating serotonin pathways. Proc Nat Acad Sci USA 2004, 101:12742-12747.

72. Carpenter RE, Korzan WJ, Bockholt C, Watt MJ, Forster GL, Renner KJ Summers $\mathrm{CH}$ : Corticotropin releasing factor influences aggression and monoamines: modulation of attacks and retreats. Neuroscience 2009, 158:412-425.

73. Woodley SK, Moore MC: Ovarian hormones influence territorial aggression in free-living female mountain spiny lizards. Horm Behav 1999, 35:205-214.

74. Nilsen SP, Chan YB, Huber R, Kravitz EA: Gender-selective patterns of aggressive behaviour in Drosophila melanogaster. Proc Nat Acad Sci USA 2004, 101:12342-12347.

75. Godwin J, Sawby R, Warner RR, Crews D, Grober MS: Hypothalamic arginine vasotocin mRNA abundance across sexes and with sex change in a coral reef fish. Brain Behav Evol 2000, 55:77-84.

76. Aubin-Horth N, Desjardins JK, Martel M, Balshine S, Hofmann HA: Masculinized dominant females in a cooperatively breeding species. $\mathrm{Mol}$ Ecol 2007, 16:1349-1358.
77. Wersinger SR, Ginns El, O'Corroll AM, Lolait SJ, Young WS: Vasopressin V1b receptor knockout reduces aggressive behaviour in male mice. $\mathrm{Mol}$ Psychiatry 2002, 7:975-984.

78. Wersinger SR, Caldwell HK, Christainsen M, Young WA: Disruption of the vasopressin $1 \mathrm{~b}$ receptor gene impairs the attack component of aggressive behaviour in mice. Genes Brain Behav 2007, 6:653-660.

79. Walther DJ, Bader M: A unique central tryptophan hydroxylase isoform. Biochem Pharmacol 2003, 66:1673-1680.

80. Ogawa S, Eng V, Taylor J, Lubahn DB, Korach KS, Pfaff DW: Roles of estrogen receptor- $\alpha$ gene expression in reproduction-related behaviors in female mice. Endocrinology 1998, 139:5070-5081.

81. Bredt DS, Snyder SH: Nitric oxide, a novel neuronal messenger. Neuron 1992, 8:3-11.

82. Nelson RJ, Demas GE, Huang PL, Fishman MC, Dawson VL, Dawson TM Snyder SH: Behavioural abnormalities in male mice lacking neuronal nitric oxide synthase. Nature 1995, 378:383-386

83. Gammie SC, Nelson RJ: Maternal aggression is reduced in neuronal nitric oxide synthase-deficient mice. J Neurosci 1999, 19:8027-8035.

84. Filby AL, Tyler CR: Molecular characterization of estrogen receptors 1, 2a, and $2 \mathrm{~b}$ and their tissue and ontogenic expression profiles in fathead minnow (Pimephales promelas). Biol Reprod 2005, 73:648-662.

85. Ferris CF, Potegal M: Vasopressin receptor blockade in the anterior hypothalamus suppresses aggression in hamsters. Physiol Behav 1988, 44:235-239.

86. Bewlig A, Fowler J: Fish on Prozac: effect of serotonin reuptake inhibitors on cognition in goldfish. Behav Neurosci 2008, 122:426-432.

doi:10.1186/1471-2164-11-498

Cite this article as: Filby et al: Unravelling the neurophysiological basis of aggression in a fish model. BMC Genomics 2010 11:498.

\section{Submit your next manuscript to BioMed Central and take full advantage of:}

- Convenient online submission

- Thorough peer review

- No space constraints or color figure charges

- Immediate publication on acceptance

- Inclusion in PubMed, CAS, Scopus and Google Scholar

- Research which is freely available for redistribution

Submit your manuscript at www.biomedcentral.com/submit
Ciomed Central 